\title{
Nerve Sheath Myxoma (Neurothekeoma) of Cerebellopontine Angle: Case Report of a Rare Tumor with Brief Review of Literature
}

\section{Serebellopontin Açının Sinir Kılıfı Miksoması (Nörotekeoma): Nadir Bir Tümörün Olgu Sunumu ve Literatürün Kısa Bir Gözden Geçirilmesi}

\author{
Mukul VIJ ${ }^{1}$, Sushila JAISWAL ${ }^{2}$, Vinita AGRAWAL ${ }^{2}$, Awadesh JAISWAL ${ }^{3}$, Sanjay BEHARI ${ }^{3}$ \\ ${ }^{1}$ Christian Medical College, Department of Pathology, Vellore, India \\ ${ }^{2} S G P G I M S$, Department of Pathology, Lucknow, India \\ ${ }^{3} S G P G I M S$, Department of Neurosurgery, Lucknow, India
}

Correspondence address: Mukul VIJ / E-mail: mukul.vij.path@gmail.com

\begin{abstract}
Nerve sheath myxoma (neurothekeoma) are rare benign nerve sheath tumors, usually arising in the skin of the head and neck region and upper extremities in young females. To the best of author's knowledge only two cases of intracranial neurothekeoma have been published in the English literature. These tumors were located in the parasellar area and in middle cranial fossa. This is the first case report of cerebellopontine angle neurothekeoma and third case report of intracranial neurothekeoma. This patient, a 45-year-old female, presented to us with complaints of right side progressive hearing loss for 12 months and swaying during walking for 8 months. Histologically the tumor had lobular appearance with spindle or stellate cells embedded in abundant myxoid background. The tumor cells were diffusely positive for S100. The patient was symptom free at eight month follow up.
\end{abstract}

KEYWORDS: Nerve sheath myxoma, Neurothekeoma, Intracranial, Cerebellopontine angle

öz

Sinir kılıfı miksoması (nörotekeoma) nadir benign sinir kılıfı tümörüdür ve genellikle genç kadınlarda üst ekstremiteler ve baş ve boyun bölgesi cildinden köken alır. Yazarın bildiği kadarıyla İngilizce literatür sadece iki intrakraniyal nörotekeoma vakası bildirmiştir. Bu tümörler parasellar bölgede ve orta kraniyal fossada yer almıştır. Bu vaka ilk serebellopontin açı nörotekeoması raporu ve üçüncü intrakraniyal nörotekeoma raporudur. Hasta 45 yaşında bir kadındı ve bize 12 aydır sağ taraflı progresif işitme kaybı ve 8 aydır yürürken sallanma yakınmalarıyla başvurdu. Histolojik olarak tümörün bol miktarda miksoid zemine gömülü mekik veya stellat hücrelerle lobuler bir görünümü vardı. Tümör hücreleri S100 için difüz pozitifti. Hasta sekiz aylık takipte semptomsuzdu.

ANAHTAR SÖZCÜKLER: Sinir kılıfı miksoması, Nörotekeoma, İntrakraniyal, Serebellopontin açı

\section{INTRODUCTION}

Neurothekeomas are benign tumors of probable nerve sheath origin. They were described originally in 1969 by Harkin and Reed who used the name nerve sheath myxoma (3). In 1980, Gallager and Helwig published a series of dermal tumors that had similar features, coining the term "neurothekeoma" (2). Other names for these tumors that have been used by different authors include plexiform myxoma, pacinian neurofibroma, cutaneous lobular neuromyxoma, and perineurial myxoma implying uncertainty regarding their true "histogenesis" or precise line of differentiation (8). Neurothekeoma most commonly occurs in the skin of young women and typically involves head and neck but less frequently can also involve extracutaneous sites, such as breast, oral cavity, spinal intradural space, and hypopharynx $(1,4,8,12)$. Although neuroectodermal orgin is the commonly accepted theory for its histogenesis, only two cases its intracranial counterpart have been reported so far. The two reported tumors were located in parasellar area and in middle cranial fossa $(7,9)$. To the best of authors knowledge, the current report is first in world literature with neurothekeoma located at cerebellopontine angle.

\section{CASE REPORT}

A 45-year-old lady presented to us with the complaints of right-sided progressive hearing loss for 12 months and swaying during walking for 8 months. There was no history of associated vomiting, seizure or loss of consciousness. Her physical examination was normal. Neurological examination revealed that her higher mental function was normal. Pupils were bilaterally normal size reacting to light. The corneal reflex was impaired on the right side but there was no 
facial hypoesthesia. There was no facial asymmetry. Right sided sensorineural hearing loss and right hemispheric cerebellar signs were present. Her routine haemogram and biochemical parameters were within normal limits. Computerized tomography (CT) scan showed a hypodense lesion in the right cerebellopontine angle (Figure 1A). Magnetic resonance imaging (MRI) brain showed a $3 X 3 \mathrm{~cm}$ extra-axial mass in the right cerebello-pontine angle region, which was hypointense on T1 (Figure 1B) and hyperintense on T2 (Figure 1C) weighted images. The mass was enhancing on contrast administration (Figure 1D) and was extending into the internal auditory meatus with the $7^{\text {th }}$ and $8^{\text {th }}$ cranial nerve complex. Under general anesthesia, right retromastoid craniectomy and total tumor excision were performed in the park bench position. Intra-operatively the tumor was extra-axial, soft and moderately vascular with good plane of cleavage from adjacent structures. All adjacent vessels and nerves were identified and preserved. The tissue was sent for histopathology.
The tissue was fixed in $10 \%$ buffered formalin for 12 hours and processed for routine histology. Paraffin sections were stained with hematoxylin and eosin, alcian blue at $\mathrm{pH} 2.5$ and 0.5 , and reticulin. Immunohistochemistry for S-100, glial fibrillary acidic protein (GFAP), epithelial membrane antigen (EMA) and neurofilament (NF) was performed. The tumor aggregate measuring $1.5 \times 1 \times 1 \mathrm{cms}$ was processed for routine histology. Paraffin sections were stained with hematoxylin and eosin and alcian blue at $\mathrm{Ph}$ 2.5. The sections on routine light microcopy showed a tumor composed of lobules with intervening thin fibrovascular septae (Figure 2A). The lobules showed spindle cells in whorls and short fascicles embedded in an abundant myxoid stroma. The tumor was hypocellular. The spindle cells displayed elongated spindle nuclei, bland chromatin and variable amount of ill-defined cytoplasm (Figure 2B). No mitotic activity, necrosis or atypia was noted in the tumor cells. Abundant mucin was noted in the alcian blue stain (Figure 2C). Tumor cells were reticulin rich (Figure 2D). No binucleation or multinucleation was noted. The
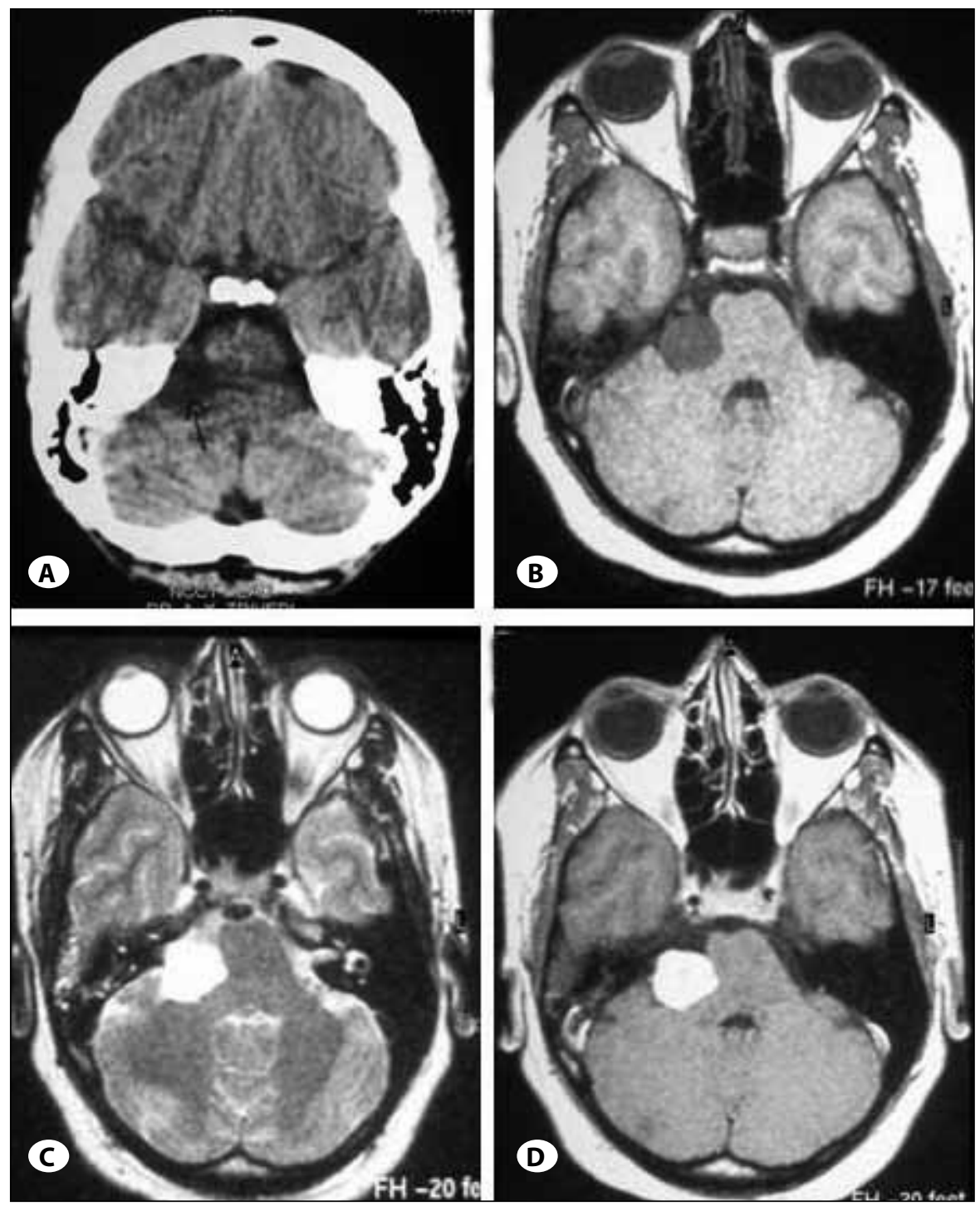

Figure 1: Radiologic findings: (A) CT scan axial section showing hypodense lesion in the right cerebellopontine angle. (B) MRI axial sections T1 image showing hypointese lesion. (C) MRI axial sections T2 image showing hyperintense lesion. (D) T1 contrast image showing bright enhancement. 

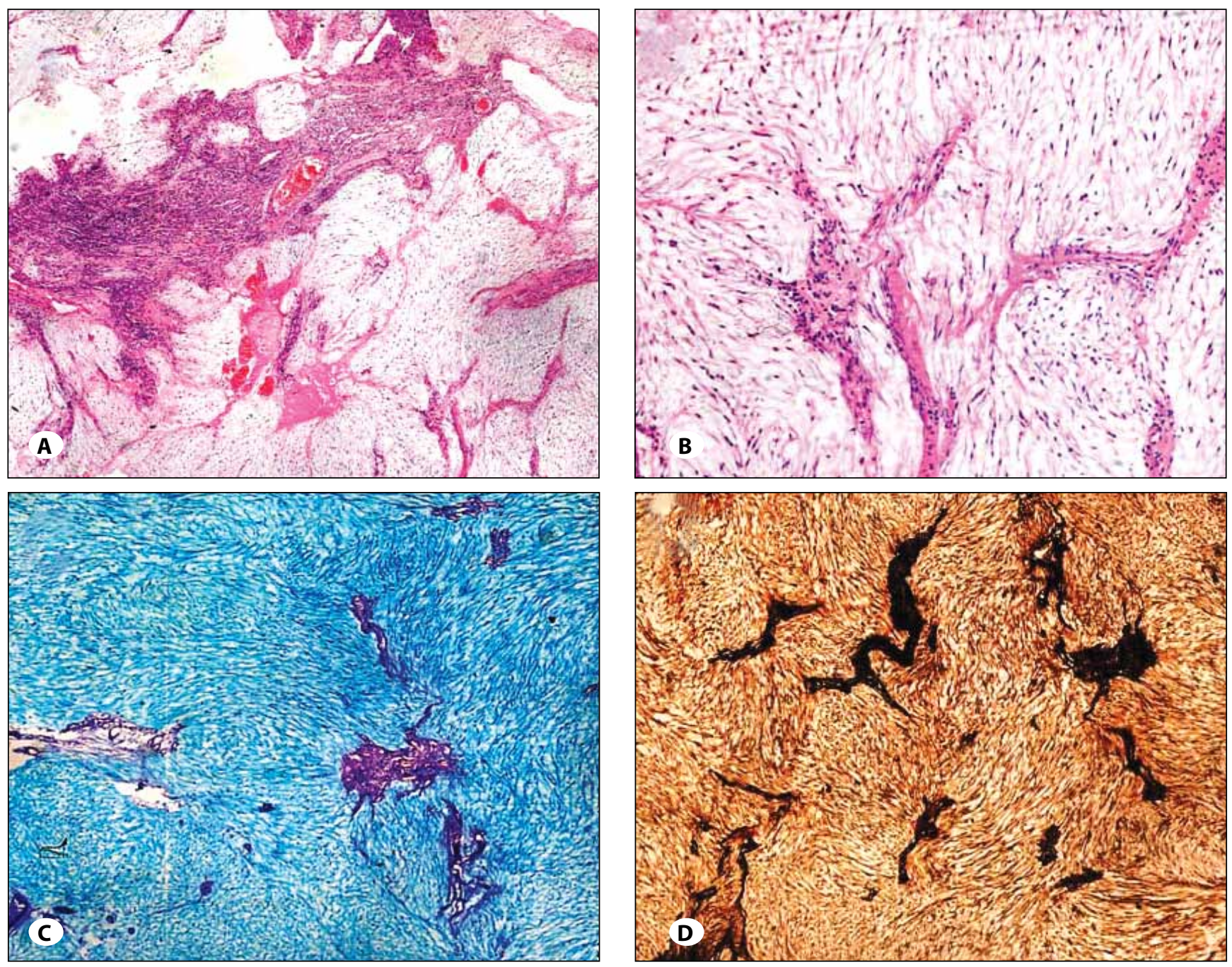

Figure 2: Histopathological findings: (A) lobules composed of sparsely distributed tumor cells with intervening connective tissue septa. (B) Higher power displaying spindle or stellate nuclei and abundant myxoid background. (C) abundant mucin in tumor. (D) reticulin in tumor.

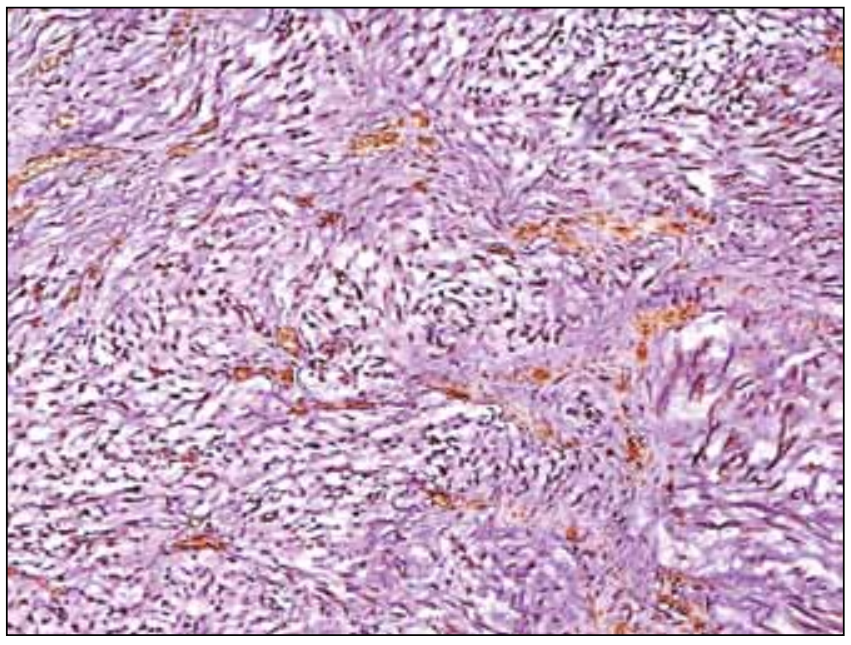

Figure 3: Diffuse nuclear S100 immunopositivity. tumors cells were diffusely immunorecative for S100 (Figure 3), and negative for EMA, GFAP and NF. We labeled the tumor as neurothekeoma (benign nerve sheath myxoma). Postoperatively, the patient had mild worsening of the right facial nerve and was discharged on the $7^{\text {th }}$ post-operative day. At 6 month follow up, her facial nerve functions improved completely and she was symptom free.

\section{DISCUSSION}

The current case is first case report of neurothekeoma at cerebellopontine angle. Historically, this tumour has been subclassified as cellular, mixed, or myxoid type. The classical myxoid variant, also regarded by some authors as nerve sheath myxoma, has a distinctive histologic appearance characterized by a lobulated, well-circumscribed proliferation of stellate, spindle-shaped and, less commonly, epithelioid cells floating in abundant mucin with intervening condensed fibro-connective tissue. Most ultrastructural and immunohistochemical studies on this type have favoured an 
origin from Schwann cells over the alternative of perineural fibroblasts $(2,3)$. Such lesions are strongly and diffusely S100 positive. The cellular type is hypercellular, predominantly nested, and can show cellular atypia. The hypercellular component is composed of epithelioid cells with minimal mucin in the interstitium. The tumour with combined cellular and myxoid variant is classified as intermediate type. The current case was composed of lobules with intervening thin fibrovascular septae. The lobules show spindle cells in whorls and short fascicles embedded in an abundant myxoid stroma. This morphology corresponds to the myxoid or classical variant.

S100 positivity suggests a schwannian origin in our case. The histogenesis has also been suggested from perineural cells of the nerve twigs around blood vessels. Perineural cells are positive for EMA and negative for S100 protein. Our case was EMA negative. The previously reported case located at the parasellar location suggests possible origin from dural nerve twigs (9). This case was very much similar to our case. The tumour was lobular with stellate cells with reticular cellular processes within abundant basophilic matrix and the tumour cells were also diffusely positive for $\mathrm{S100}$. Our case was also reticulin rich. The case by $\mathrm{Pal}$ et al. was an intermediate cellular variant as it slowed spindle as well as epithelioid cells in a background of abundant stroma intervened by scanty collagen fibres. The authors also suggested that these cases may also arise from the persistent pleuripotent cell resting inside brain parenchyma, which on suitable environment could undergo divergent differentiation (7). Immunohistochemistry for $\mathrm{S} 100$ in their case was variable and tumour cells at periphery of lobules were immunoreactive, in contrast to our case which showed strong diffuse $\mathbf{S 1 0 0}$ immunostaining throughout the tumour.

Radiologically the differential diagnosis includes schwannoma, meningioma, and epidermoid. On MRI schwannoma reveals a well-circumscribed, sometimes cystic and often heterogeneously enhancing mass. On MRI, meningiomas are typically isodense, contrast-enhancing dural masses. Some, like microcystic meningiomas, may show little enhancement on CT and MRI. Calcification is best seen on CT scan. A characteristic feature of meningiomas is the so-called 'dural tail' surrounding the dural perimeter of the mass. The typical appearance of epidermoid is a hyperintense lesion in the left cerebellopontine angle.

The diagnosis of intracranial nerve sheath myxoma is important as various intracranial myxoid tumours other than neurothekeoma may be encountered by the neurosurgeon. Gliomas, meningiomas, and sarcomas may show myxoid degeneration $(7,9)$. Cardiac myxomas metastasizing to the brain and soft tissue myxomas penetrating the skull may be seen. A few myxoid tumours arising within the spinal cord, pituitary fossa and posterior fossa have been reported $(5,6,11)$ Myxoid neurofibroma is closely related and neurothekeoma were originally introduced as a variant of neurofibroma. Intraspinal neurothekeoma could well have been diagnosed earlier as myxoid neurofibroma. However, myxoid neurofibromas do not show mulinodularity and show presence of intratumoral neuritis. Perineuromas are rare tumours composed exclusively of perineural cells. There tumour appear myxomatous, but no lobulation is noted.

Neurothekeoma is an accepted clinicopathologic entity in cutaneous pathology. It has a distinctive histopathologic appearance. Immunohistoshemistry may contribute to the correct diagnosis. Neurothekeoma is a benign tumor and is unlikely to recur if totally excised. The identical characteristics of our intracranial tumour indicates that the intracranial variant can also be cured by complete excision. In conclusion, this report constitutes the third well documented case of intracranial neurothekeoma. Analysis of larger number of cases at intracranial location is required to identify definite cell of origin of these rare tumours.

\section{REFERENCES}

1. Chow LT, Ma TK, Chow WH: Cellular neurothekeoma of thehypopharynx. Histopathology 30:192-194, 1997

2. Gallager RL, Helwig EB: Neurothekeoma-a benign cutaneoustumor of neural origin. Am J Clin Pathol 4:759-764, 1980

3. Harkin JC, Reed RJ: Solitary benign nerve sheath tumors, Myxoma of the nerve sheath. In: Firminger $\mathrm{HI}$, (ed). Tumors of the Peripheral Nervous System. Washington, DC: Armed Forces Institute of Pathology 1969:60-64

4. Katsourakis M, Kapranos N, Papanicolaou SI, Patrikiou A: Nerve-sheathmyxoma (neurothekeoma) of the oral cavity: A case report andreview of the literature. J Oral Maxillofac Surg 54:904-906, 1996

5. Klein MV, Schwaighofer BW, Sobel DF, Hesselink JR: Primary myxoma of the posterior fossa. Neuroradiology 32:250-251, 1990

6. Nagatani M, Mori S, Takimoto N, Arita N, Ushio Y, Hayakawa T, Gen M, Uozumi T, Mogami H: Primary myxoma in the pituitary fossa: Case report. Neurosurgery 20:329-331, 1987

7. Pal L, Bansal K, Behari S, Sagar BC, Gupta RK, Gupta RK, Shankar SK: Intracranial neurothekeoma--a rare parenchymal nerve sheath myxoma of the middle cranial fossa. Clin Neuropathol 21:47-51, 2002

8. Paulus W, Jellinger K, Perneczky G: Intraspinal neurothekeoma (nerve sheath myxoma). A report of two cases. Am J Clin Pathol 95:511-516, 1991

9. Paulus W, Warmuth-Metz $M$, Sörensen N: Intracranial neurothekeoma (nerve-sheath myxoma). Case report. J Neurosurg 79:280-282, 1993

10. Plaza JA, Torres-Cabala C, Evans H, Diwan AH, Prieto VG: Immunohistochemical expression of S100A6 in cellular neurothekeoma: Clinicopathologic and immunohistochemical analysis of 31 cases. Am J Dermatopathol 31:419-422, 2009

11. Pasaoglu A, Patiroglu TE, Orhon C, Yildizhan A: Cervical spinal intramedullary myxoma in childhood. Case report. J Neurosurg 69:772-774, 1988

12. Wee $A$, Tan CE, Raju GC: Nerve sheath myxoma of the breast. A light and electron microscopic, histochemical and immunohistochemical study. Virchows Arch A Pathol Anat Histopathol 416:163-167, 1989 